\title{
HUBUNGAN LUAR NEGERI NUSA TENGGARA BARAT DENGAN MALAYSIA DALAM BIDANG PENDIDIKAN TINGGI
}

\author{
Ahmad Saifuddin Bukhari ${ }^{1}$, RMT Nurhasan Affandi², Dina Yulianti ${ }^{3}$ \\ ${ }^{1}$ Program Studi Magister Ilmu Politik Fakultas Ilmu Sosial \& Ilmu Politik \\ Universitas Padjadjaran, \\ ahmad18024@mail.unpad.ac.id \\ 2 Program Studi Ilmu Hubungan Internasional Fakultas Ilmu Sosial \& Ilmu \\ Politik \\ Universitas Padjadjaran, \\ 3 Program Studi Ilmu Hubungan Internasional Fakultas Ilmu Sosial \& Ilmu \\ Politik \\ Universitas Padjadjaran
}

\begin{abstract}
This article examines the factors and reasons why West Nusa Tenggara (NTB) maintains foreign relations in the field of higher education with the Malaysian Ministry of Education. The study was conducted using a descriptive qualitative method with the concept of paradiplomacy as an analytical tool. Data collection was carried out by literature study and also interviews with related sources. The results of this study indicate that NTB is active in establishing foreign relations in the field of higher education (including with Malaysia) because it is driven by external and internal factors. External factors come from globalization and regionalization, while internal factors are influenced by decentralization and the role of regional leaders. Meanwhile, the reason for NTB to establish foreign relations with the Malaysian Ministry of Education is because Malaysia is seen to be able to assist NTB in fulfilling its pragmatic interests in the field of higher education, namely the running of a higher education scholarship program abroad (Malaysia) at low cost, and good quality education, and opportunities to expand international networks. Meanwhile, the Malaysian Ministry of Education is willing to establish a relationship with NTB to increase the number of international students in Malaysia.
\end{abstract}

Keyword: paradiplomacy; higher education; scholarship; West Nusa Tenggara

\section{PENDAHULUAN}

Hubungan luar negeri ataupun aktivitas lintas batas negara oleh pemerintah daerah atau aktor subnasional telah menjadi fenomena umum yang terjadi di berbagai belahan dunia. Globalisasi dan desentralisasi di banyak negara disebut sebagai penyebab utama meluasnya fenomena hubungan luar negeri oleh aktor subnasional (Schiavon, 2019). Globalisasi telah menyebabkan batas-batas antar negara menjadi kabur dan membuka 
ruang bagi aktor-aktor selain negara (termasuk aktor subnasional) untuk terlibat dalam aktivitas internasional (Mingus, 2006; Schiavon, 2019). Desentralisasi di banyak negara juga menyebabkan pemerintah daerah menjadi semakin terlibat dalam dunia internasional karena desentralisasi membuat mereka memiliki otonomi yang lebih besar dalam mengelola daerah mereka, termasuk juga terlibat dalam aktivitas internasional (Garesché, 2007).

Hubungan luar negeri oleh pemerintah daerah di Indonesia sendiri meluas setelah adanya proses desentralisasi pasca reformasi yang ditandai dengan diterbitkannya UU No. 32 Tahun 2004 tentang tentang Pemerintah Daerah, UU No. 37 Tahun 1999 tentang Hubungan Luar Negeri, dan UU No. 24 Tahun 2000 tentang Perjanjian Internasional. Berdasarkan undangundang tersebut pemerintah daerah disebut dapat menjalankan hubungan luar negeri dan menandatangani perjanjian internasional setelah mendapatkan persetujuan dari pemerintah pusat (Mukti, 2013).

Nusa Tenggara Barat (NTB) adalah salah satu daerah di Indonesia yang aktif menjalankan hubungan luar negeri dengan berbagai pihak mancanegara. Sejak dipimpin oleh Gubernur Zulkieflimansyah, Pemerintah Provinsi (Pemprov) NTB banyak menjalin hubungan luar negeri dalam bidang pendidikan tinggi. Mereka menjalin hubungan luar negeri dengan lembaga pendidikan tinggi ataupun pemerintah asing dalam bidang pendidikan tinggi untuk mewujudkan program "1000 Cendekia", yaitu program beasiswa pendidikan tinggi untuk mengirim sejumlah putra dan putri daerah belajar ke luar negeri setiap tahunnya (Pemprov NTB, t.thn.). Program beasiswa pendidikan tinggi merupakan bentuk dari realisasi misi "NTB Sehat dan Cerdas" melalui peningkatan kualitas sumber daya manusia yang berdaya saing dan berwawasan global (Pemprov NTB, 2019c, pp. 237-238).

Hubungan luar negeri dalam bidang pendidikan tinggi salah satunya dilaksanakan oleh NTB bersama dengan Kementerian Pendidikan Malaysia (KPM). Keduanya resmi menjalin kerja sama sejak 23 Agustus 2019, ketika Lembaga Pengembangan Pendidikan NTB (LPPNTB) menandatangani MoU kerja sama dengan 18 perguruan tinggi Malaysia di kantor KPM di Putrajaya. Penandatanganan kesepakatan tersebut didampingi langsung oleh Gubernur 
NTB Zulkieflimansyah dan Menteri Pendidikan Malaysia Dr. Maszlee Malik. Berdasarkan kesepakatan kerja sama ini, NTB mengirim sejumlah mahasiswa setiap tahunnya untuk mengikuti pendidikan lanjutan di Malaysia. Pada tahun 2019, 152 mahasiswa NTB telah diberangkatkan ke Malaysia untuk menempuh studi S2 di berbagai perguruan tinggi Malaysia (Pemprov NTB, 2019b).

Penulis dalam hal ini berusaha untuk mengkaji faktor dan alasan NTB menjalin hubungan luar negeri dengan Malaysia dalam bidang pendidikan tinggi. Adapun kajian terdahulu menunjukkan bahwa aktor sub negara melaksanakan hubungan luar negeri karena alasan dan faktor yang berbedabeda. Misalnya hubungan luar negeri oleh pemerintah Barcelona dalam bidang budaya dilaksanakan karena didorong oleh faktor globalisasi ekonomi dan mereka berusaha untuk membangun citra baik budaya mereka agar dapat menarik investasi asing dan mempromosikan pembangunan daerah (Zamorano \& Morató, 2014). Hubungan luar negeri yang dijalin oleh Yunan dengan negara-negara Sub Wilayah Mekong Raya tidak hanya didorong oleh faktor globalisasi, tetapi juga faktor ekonomi politik domestik, yaitu dijadikan sebagai proyek pembangunan subnasional yang dirancang untuk menarik bantuan ekonomi dari pemerintah pusat (Tubilewicz, 2016). Sementara kota Seoul menjalankan hubungan luar negeri untuk pengembangan ekonomi kreatif (Nur Alam et al., 2021). Pemerintah daerah di Indonesia, seperti pemerintah semarang yang menjadikan aktivitas lintas batas negara sebagai sarana untuk mencapai kepentingan ekonomi, yaitu menarik investasi asing dan perluasan pasar (Damayanti, 2018).

Sementara itu, kajian tentang hubungan luar negeri NTB sebelumnya telah dilakukan oleh Subarkah (2018) dan Pratama (2020). Keduanya mengkaji aktivitas lintas batas negara yang dilakukan oleh NTB dengan pendekatan yang berbeda. Subarkah (2018) mengkaji tentang diplomasi NTB dalam pariwisata halal dengan pendekatan diplomasi publik yang hasilnya menunjukkan bahwa pariwisata halal dijadikan sebagai alat diplomasi publik oleh NTB terhadap publik global untuk membangun citra sebagai daerah ramah wisatawan muslim. Sementara Pratama (2020) mengkaji tentang hubungan luar negeri NTB pada tahun 2013-2018 dengan pendekatan 
konsep paradiplomasi dan teori pilihan rasional. Hasilnya menunjukkan bahwa terdapat perubahan arah kebijakan NTB dalam melaksanakan hubungan luar negeri pada tahun 2018 yang disebabkan oleh perbedaan rasionalitas dua pemimpin daerah. Berbeda dengan dua penelitian tersebut, artikel ini berfokus pada pembahasan tentang faktor dan alasan NTB dalam menjalin hubungan luar negeri dengan Malaysia dalam bidang pendidikan tinggi.

Adapun metode penelitian yang digunakan dalam penelitian ini adalah deskriptif kualitatif dan menggunakan konsep paradiplomasi sebagai alat analisis. Teknik pengumpulan data dilakukan melalui studi kepustakaan dan wawancara. Wawancara dilakukan terhadap institusi-institusi terkait, yaitu Dinas Pendidikan dan Kebudayaan (Dikbud) NTB, Biro Administrasi Kerjasama NTB dan Lembaga Pengembangan Pendidikan NTB (LPPNTB), dan Kedutaan Besar Malaysia untuk Indonesia di Jakarta. Sementara studi kepustakaan dilakukan melalui dokumen dan laporan resmi dari pemerintah, laporan penelitian, artikel jurnal, dan artikel berita daring. Selanjutnya

\section{PEMBAHASAN}

\section{Paradiplomasi dalam Konteks Hubungan Luar Negeri NTB}

Hubungan luar negeri oleh pemerintah daerah atau aktor sub negara dalam studi hubungan internasional biasanya dijelaskan dalam konsep paradiplomasi. Istilah paradiplomasi sendiri merupakan singkatan dari "parallel diplomacy" yang didefinisikan sebagai aktivitas internasional ataupun hubungan luar negeri oleh entitas subnegara (Mukti, 2013; Paquin, 2004).

Lebih jelasnya paradiplomasi didefinisikan oleh Duchacek dan Soldatos sebagai aktivitas, aksi, kontak, dan hubungan eksternal dari aktor subnasional dengan aktor-aktor internasional seperti negara, sub-negara, perusahaan transnasional, organisasi internasional, organisasi masyarakat sipil, ataupun aktor-aktor lainnya (Schiavon, 2019, p. 6). Sejalan dengan mereka, Kuznetsov (2015, pp. 30-31) juga mendefinisikan paradiplomasi sebagai komunikasi politik yang dilakukan oleh pemerintah daerah dengan 
aktor-aktor internasional demi mendapatkan keuntungan-keuntungan tertentu, baik berupa keuntungan ekonomi, budaya, politik, maupun yang lainnya.

Kuznetsov (2015, pp. 102-104) lebih lanjut menjelaskan bahwa pemerintah daerah melaksanakan aktivitas paradiplomatik disebabkan oleh beberapa faktor eksternal dan internal. Adapun faktor eksternalnya adalah: (1) globalisasi, yakni keadaan mengikisnya batas-batas antar negara sehingga memberi entitas subnegara lebih banyak kesempatan untuk mengejar kepentingan mereka tidak hanya secara domestik tetapi juga secara internasional; (2) regionalisasi, yaitu subsidiaritas yang diarahkan oleh pengaruh global atau dalam kata lain semacam "federalisasi dari luar"; (3) demokratisasi, peningkatan kemajemukan dalam proses pengambilan keputusan yang demokratis memberikan peluang perluasan paradiplomasi, dan; (4) domestikasi kebijakan luar negeri dan internalisasi politik dalam negeri, yaitu pengaruh dari mengaburnya batas antara politik dan luar negeri mendorong pemerintah subnegara melintasi batas negara untuk mempromosikan masalah "politik rendah" dan beberapa masalah "politik tinggi.

Sedangkan faktor internal penyebab pemerintah subnegara melaksanakan paradiplomasi adalah: (1) federalisasi dan desentralisasi, yaitu berkembangnya paradiplomasi yang disebabkan oleh hasil evolusi hubungan antar pemerintah (pusat dan non-pusat); (2) masalah dengan proses pembangunan bangsa, yang biasanya terjadi pada negara dengan entitas etnis, bahasa, dan budaya yang berbeda dengan penduduk lainnya sehingga mendorong mereka untuk mendapatkan pengakuan internasional; (3) efektivitas hubungan luar negeri pemerintah pusat yang tidak memadai, yaitu lemahnya pemerintah pusat dalam mengelola kebijakan luar negeri secara umum maupun bidang tertentu mendorong pemerintah sub negara yang memiliki pengetahuan dan pengalaman lebih dalam urusan internasional melaksanakan paradiplomasi; (4) unit konstituen yang asimetris, yaitu ketidaksetaraan antara daerah satu dengan lainnya dalam perkembangan ekonomi menyebabkan pemerintah daerah mengembangkan hubungan luar negeri untuk meningkatkan pertumbuhan ekonomi; (5) 
stimulus luar, yaitu pengaruh luar yang memicu internal subnegara melaksanakan paradiplomasi seperti program Uni Eropa untuk mendorong paradiplomasi lintas batas; (6) peran pemimpin daerah/partai politik, kepribadian pemimpin daerah serta ideologi politik partai daerah tertentu dapat menentukan intensitas dan jalannya keterlibatan daerah dalam urusan internasional, dan; (7) peran perbatasan, yang biasanya terjadi pada daerah yang terletak di wilayah perbatasan yang memudahkan mereka berinteraksi secara langsung dengan entitas sub negara negara lain (Kuznetsov, 2015, pp. 105-108).

Selain adanya faktor pendorong, sub negara melaksanakan hubungan luar negeri ataupun paradiplomasi juga karena adanya kepentingan yang ingin dipenuhi. Menurut Kuznetsov (2015, p. 30), kepentingan subnegara dalam paradiplomasi adalah untuk mendapatkan keuntungan-keuntungan tertentu, baik di bidang ekonomi, budaya, maupun politik. Sementara Tavares (2016, pp. 117-118) menjelaskan kepentingan sub negara bersifat pragmatis, bertarget, oportunistik, dan bahkan eksperimental. Hal ini dikarenakan paradiplomasi lebih berorientasi pada kebutuhan warga, yaitu dengan menyempurnakan perangkat yang tersedia bagi pemerintah daerah untuk mengadopsi kebijakan yang bermanfaat bagi kesejahteraan penduduk. Sehingga pemerintah daerah menjalin hubungan luar negeri dengan pihak asing yang dapat memberikan manfaat terhadap warganya.

\section{Faktor Pendorong Paradiplomasi Pendidikan Tinggi NTB}

Paradiplomasi pendidikan tinggi NTB gencar dijalankan karena didorong oleh beberapa faktor. Kuznetsov (2015, pp. 102-108) sebelumnya menjelaskan terdapat sebelas faktor eksternal dan internal yang dapat mempengaruhi pemerintah daerah melaksanakan paradiplomasi. Namun dalam kasus ini, terdapat empat faktor yang mempengaruhi NTB dalam paradiplomasi pendidikan tinggi, yaitu globalisasi, regionalisasi, desentralisasi, dan peran pemimpin daerah.

Globalisasi dalam perspektif Pemprov NTB dapat menjadi peluang dan juga tantangan. Fenomena global yang mendorong mengaburnya batas-batas antar negara tentunya dapat memberikan peluang yang besar bagi aktor 
subnasional untuk melibatkan diri mereka dalam fora internasional demi mendapatkan keuntungan-keuntungan tertentu. Khususnya dalam globalisasi pendidikan tinggi, pemprov NTB memandangnya sebagai peluang yang dapat membantu mereka meningkatkan kualitas sumber daya manusia. Mereka menyadari bahwa pendidikan tinggi pada perkembangannya telah menjadi kegiatan lintas negara, di mana program pertukaran pelajar dan kolaborasi penelitian antarnegara menjadi semakin penting (Varghese, 2008). Karena itu, perguruan tinggi menjadi sangat terbuka terhadap kemitraan dengan pihak asing untuk mendorong mobilisasi lintas negara pada pelajar, pengajar dan peneliti serta peningkatan kualitas dan kuantitas penelitian (Edwards \& Kitamura, 2019). Hal ini bagi Pemprov NTB menjadi peluang untuk dapat menjalin kemitraan internasional dalam beasiswa pendidikan tinggi dan internasionalisasi perguruan tinggi di NTB (Saputra, 2020).

Globalisasi di sisi lain juga dipandang sebagai tantangan, di mana pasar bebas menjadi semakin berkembang dan persaingan menjadi semakin terbuka. Pemprov NTB melihat hal ini harus dihadapi dengan sumber daya manusia yang berkualitas dan dapat bersaing secara nasional dan juga global. Penting bagi mereka untuk memiliki sumber daya manusia yang tidak hanya berkualitas secara akademik tetapi juga memiliki jaringan dan wawasan global yang luas. Menurut Gubernur NTB, hal itu dapat diwujudkan dengan program beasiswa pendidikan tinggi ke luar negeri dan pendidikan tinggi di NTB semakin terkoneksi dengan dunia internasional (Pemprov NTB, 2019a).

Kesadaran akan tantangan global juga muncul karena adanya tuntutan untuk pemenuhan Sustainable Development Goals (SDGs). SDGs adalah agenda internasional untuk pembangunan berkelanjutan hingga tahun 2030 yang telah disepakati oleh 159 negara termasuk Indonesia pada tahun 2015. Dengan disepakatinya SDGs oleh pemerintah Indonesia, NTB yang merupakan daerah di bawah naungan Indonesia juga harus turut mendukung pemenuhan tujuan berkelanjutan global tersebut. Dalam tuntutan pemenuhan SDGs, pembangunan sumber daya manusia menjadi prioritas utama bagi NTB dengan meningkatkan kualitas dan aksesibilitas pendidikan hingga ke jenjang yang tertinggi (Alisjahbana, 2017; Pemprov 
NTB, 2019c, pp. 226-227). Karenanya menjalin hubungan luar negeri dalam bidang pendidikan penting bagi mereka untuk mendukung pembangunan sumber daya manusia.

Faktor eksternal lainnya yaitu faktor regionalisasi hadir setelah dibentuknya ASEAN Community pada tahun 2015. ASEAN Community atau Masyarakat ASEAN merupakan upaya integrasi negara-negara Asia Tenggara dengan menciptakan masyarakat maju, damai dan makmur yang dipersatukan oleh hubungan kemitraan yang dinamis. Salah satu agenda dari Masyarakat ASEAN adalah Masyarakat Ekonomi ASEAN (MEA) yang bertujuan untuk mengintegrasikan ekonomi Asia Tenggara melalui pasar bebas. Kehadiran MEA menjadi tantangan lain bagi Pemprov NTB karena harus turut bersaing dalam pasar bebas di tingkat regional Asia Tenggara. Untuk menghadapi MEA, Pemprov NTB berusaha meningkatkan daya saing sumber daya manusianya, penguatan mutu produknya, juga mengembangkan industri yang berorientasi pada nilai tambah (Pemprov NTB, 2019c, p. 226).

Sementara itu, faktor internal seperti desentralisasi juga berpengaruh terhadap paradiplomasi Pemprov NTB dalam bidang pendidikan tinggi. Desentralisasi pemerintah Indonesia yang telah berlangsung sejak awal tahun 2000-an membuat pemerintah daerah menjadi memiliki otonomi yang lebih besar dalam menentukan arah pembangunan mereka dan juga menjalin hubungan luar negeri untuk pembangunan daerah. Permasalahan pembangunan yang menjadi salah satu perhatian utama Pemprov NTB sejak tahun 2018 adalah pembangunan manusia dan pendidikan (Muslim, 2020). Dalam hal pembangunan manusia, data BPS menunjukkan bahwa dalam satu dekade terakhir indeks pembangunan manusia (IPM) NTB termasuk yang terendah di Indonesia, yaitu berada di urutan 30 dari 35 provinsi Indonesia (BPS, 2020). Berdasarkan kondisi ini, Pemprov NTB berupaya mewujudkan misi "NTB sehat dan cerdas" yang bertujuan untuk meningkatkan IPM NTB dari 66,85 pada tahun 2018 menjadi 68,19 pada tahun 2023 (Pemprov NTB, 2019c, pp. 237-240). Salah satu upaya untuk meningkatkan IPM dilakukan melalui program beasiswa pendidikan tinggi ke 
luar negeri yang membuat Pemprov NTB menjadi aktif menjalin hubungan luar negeri dalam bidang pendidikan tinggi.

Namun di samping itu, peran pemimpin daerah juga menjadi faktor penting lainnya dalam paradiplomasi NTB. Penyebab lain NTB menjadi gencar menjalin hubungan luar negeri dalam bidang pendidikan tinggi adalah karena dipimpin oleh seorang gubernur yang memiliki karir panjang di bidang pendidikan tinggi. Gubernur NTB Zulkieflimansyah atau biasa disapa Dr. Zul merupakan seorang akademisi yang telah meniti karir sebagai pengajar dan peneliti di sejumlah kampus nasional maupun internasional sejak tahun 1994. Sebelum menjadi Gubernur NTB pada tahun 2018, Dr Zul juga telah berperan dalam pengembangan pendidikan tinggi di NTB dengan mendirikan sejumlah perguruan tinggi di pulau Sumbawa, yaitu Universitas Teknologi Sumbawa (UTS), Institut Ilmu Sosial dan Ilmu Budaya (IISBUD), dan Akademi Komunitas Alat Berat Olat Maras (Pemprov NTB, t.thn.-b).

Dalam penelitian lain juga menyebutkan faktor kepemimpinan pemimpin daerah berpengaruh terhadap kebijakan paradiplomasi NTB. Pratama (2020) menyebutkan bahwa terjadi perubahan arah paradiplomasi NTB sejak tahun 2018, setelah Dr. Zul menjabat sebagai gubernur NTB periode 2018-2023. Paradiplomasi NTB pada era gubernur NTB sebelumnya yaitu Muhammad Zainul Majdi yang memiliki latar belakang sebagai cendekiawan muslim dan pendakwah berfokus pada peningkatan perekonomian daerah melalui hubungan luar negeri untuk mempromosikan pariwisata halal NTB yang berlandaskan hukum syariah. Sementara pada era pemerintahan Dr. Zul, paradiplomasi NTB lebih berfokus pada bidang pendidikan dan investasi. Dr. Zul sendiri mengakui bahwa kebijakannya tersebut dipengaruhi oleh pengalamannya sebelum menjabat sebagai gubernur (Pratama, 2020, p. 72).

\section{Hubungan Luar Negeri NTB dengan Kementerian Pendidikan Malaysia}

Hubungan luar negeri Pemprov NTB dengan KPM berawal sejak Pemprov NTB bersama dengan lembaga mitra mereka yaitu LPPNTB menyelenggarakan acara pameran beasiswa Internasional Education and Scholarship Expo (IESE) di aula Lombok Epicentrum Mall pada 15 Desember 
2018. Acara ini mengundang berbagai perguruan tinggi mancanegara dan beberapa perwakilan Kedutaan dan Konsulat Jenderal (Konjen) negaranegara sahabat, termasuk Kedutaan Besar Malaysia di Jakarta (Diskominfo NTB, 2018). Pemprov NTB melalui IESE berupaya untuk memperkenalkan program beasiswa mereka dan mempromosikan kerja sama internasional dalam bidang pendidikan tinggi.

Upaya Pemprov NTB tersebut disambut baik oleh perwakilan dari Malaysia yang menghadiri IESE. Sehari setelah IESE, Gubernur NTB bersama dengan sejumlah rektor universitas di NTB melakukan pertemuan dengan delegasi dari Kedutaan Besar Malaysia dan Majlis Dekan Pengajian Siswazah (MDPS) Malaysia. Dalam pertemuan tersebut, kedua pihak mendiskusikan tentang peluang hubungan pendidikan tinggi antara keduanya. Gubernur NTB memperkenalkan tentang program Beasiswa NTB "1000 Cendekia" dan keseriusan pemerintahannya dalam meningkatkan kualitas pendidikan dan sumber daya manusia di NTB. Pihak Kedutaan Besar Malaysia dan MDPS yang mewakili KPM mengungkapkan ketertarikan mereka terhadap program tersebut dan bersedia untuk membantu NTB menyediakan beasiswa pendidikan tinggi luar negeri ke universitasuniversitas di Malaysia (Humas NTB, 2018). Tawaran ini ditanggapi positif oleh Gubernur NTB dan bersedia menjalin komunikasi lebih lanjut terkait tawaran beasiswa dari KPM. Pertemuan antara keduanya menghasilkan kesepahaman untuk menjalin hubungan pendidikan tinggi (Novilia, 2020).

Setelah melalui proses penjajakan dan negosiasi dalam beberapa bulan, Pemprov NTB dan KPM sepakat untuk menjalin kerja sama dalam bidang pendidikan tinggi yang ditandai dengan penandatanganan MoU oleh direktur LPPNTB dengan 18 rektor perguruan tinggi Malaysia pada 23 Agustus 2019. Adapun 18 perguruan tinggi Malaysia tersebut adalah Universiti Utara Malaysia (UUM), Universiti Kebangsaan Malaysia (UKM), Universiti Pendidikan Sultan Idris (UPSI), Universiti Sains Malaysia (USM), Universiti Teknikal Malaysia Melaka (UTeM), Universiti Teknologi Mara (UiTM), University of Nottingham Malaysia (UNiM), Universiti Sultan Zainal Abidin (UNISZA), Universiti Malaysia Terengganu (UMT), Universiti Malaysia Perlis (UNIMAP). Tujuan utama dari hubungan luar negeri antara kedua pihak 
adalah untuk kerja sama dalam beasiswa pendidikan tinggi. Hingga tahun 2021, berdasarkan kesepakatan dengan universitas-universitas Malaysia, NTB telah memberangkatkan 254 orang untuk menempuh studi magister (S2) di beberapa universitas Malaysia, yaitu UUM, UKM, UPSI, USM, dan UTeM (Novilia, 2020).

Hubungan antara LPPNTB dengan 18 universitas Malaysia tersebut utamanya adalah untuk beasiswa pendidikan tinggi, namun tidak menutup kemungkinan akan meluas pada bidang lainnya yang berkaitan dengan pendidikan tinggi seperti keinginan dari Gubernur NTB dan Menteri Pendidikan Malaysia. Hal ini dikarenakan MoU yang mereka tandatangani memiliki ruang lingkup yang luas di bidang pendidikan tinggi (Harun 2020). Sehingga hubungan ini juga membuka peluang untuk kolaborasi antar universitas di kedua pihak.

\section{Alasan NTB dan KPM Menjalin Hubungan Luar Negeri dalam Bidang Pendidikan Tinggi}

Pemprov NTB menjadikan Malaysia menjadi salah satu target paradiplomasi pendidikan tinggi mereka karena adanya kepentingan dan keuntungan tertentu yang ingin dicapai. Berdasarkan penjelasan dari Kuznetsov (2015, pp. 30-31), paradiplomasi dilakukan dengan tujuan untuk mendapatkan keuntungan-keuntungan tertentu. Penjelasan tersebut dapat dipahami bahwa paradiplomasi dilakukan oleh aktor subnasional untuk meraih kepentingan domestik mereka. Namun, paradiplomasi berbeda dengan diplomasi negara yang didasarkan pada kepentingan nasional yang kompleks. Kepentingan daerah dalam paradiplomasi memiliki tujuan yang lebih pragmatis, bertarget, oportunistik, dan bahkan terkadang eksperimental (Tavares, 2016, pp. 116-118). Kepentingan pragmatis, bertarget dan oportunistik ini maksudnya adalah kepentingan untuk memberikan manfaat dan keuntungan secara langsung terhadap daerah. Misalnya kepentingan paradiplomasi NTB terhadap KPM adalah untuk mendapatkan keuntungan di bidang pendidikan berupa dukungan terhadap program Beasiswa NTB. 
Pendidikan tinggi di Malaysia menurut perspektif dari Pemprov NTB dapat memberikan peluang yang besar terhadap program Beasiswa NTB. Pertama, biaya pendidikan tinggi di Malaysia yang terkenal sangat terjangkau merupakan salah satu peluang yang menjanjikan bagi Pemprov NTB. Biaya pendidikan yang murah artinya akan memberikan kesempatan yang lebih besar bagi masyarakat NTB untuk belajar ke luar negeri. Karena Pemprov NTB bisa menyediakan beasiswa yang lebih banyak bagi masyarakat NTB, misalnya biaya beasiswa untuk satu orang ke Eropa sama dengan biaya beasiswa lima orang ke Malaysia (Novilia, 2020). Selain itu, jarak NTB ke Malaysia yang tidak terlalu jauh juga menambah peluang untuk biaya beasiswa pendidikan ke Malaysia menjadi semakin murah (Saputra, 2020). Terutama setelah dibukanya penerbangan langsung dari Bandara Internasional Lombok ke Bandara Kuala Lumpur Malaysia.

Kedua, Malaysia adalah salah satu negara tujuan belajar yang banyak diminati mahasiswa internasional di seluruh dunia. Menurut data dari Institut Statistik UNESCO tahun 2014, Malaysia berada pada urutan ke-12 sebagai negara tujuan belajar yang paling populer dengan jumlah mahasiswa internasional mereka mencapai 63.625 mahasiswa. Jumlah tersebut lebih tinggi dari pada jumlah mahasiswa internasional yang belajar di Singapura (urutan ke-18), yaitu 52.959 mahasiswa (Guardian, 2014). Mahasiswa internasional di Malaysia datang dari 120 negara di berbagai benua Asia, Eropa, Amerika, dan Afrika (UNESCO, t.thn.).

Tingginya jumlah mahasiswa internasional di Malaysia tersebut menjadi alasan lain bagi Pemprov NTB menjalankan paradiplomasi terhadap KPM. Berdasarkan Gubernur NTB, tujuan dari program Beasiswa NTB tidak hanya untuk peningkatan pengetahuan tetapi juga untuk memperluas jaringan dan wawasan global masyarakat NTB (Saputra, 2020). Meskipun Malaysia memiliki kebudayaan yang tidak jauh berbeda dengan Indonesia, namun banyaknya jumlah mahasiswa mancanegara yang ada di sana membuka kesempatan bagi mahasiswa NTB untuk memperluas jaringan dan wawasan internasional mereka. Sistem perkuliahan di Malaysia yang sebagian besar dilaksanakan dengan menggunakan bahasa Inggris (Chapman \& Chien, 2014) juga memberikan akses yang lebih baik untuk 
perluasan wawasan internasional sekaligus peningkatan kemampuan bahasa internasional.

Ketiga, kualitas pendidikan tinggi di Malaysia juga menjadi pertimbangan lain bagi Pemprov NTB. Meskipun biaya pendidikannya yang relatif rendah, tetapi kualitas pendidikan tinggi di Malaysia cukup baik (Novilia, 2020). Berdasarkan survei dari QS Higher Education System Strength Ranking 2018, kualitas sistem pendidikan tinggi Malaysia berada pada peringkat ke-25 secara global. Peringkat Malaysia tersebut lebih tinggi dibandingkan dengan negara-negara Asia Tenggara lainnya, artinya Malaysia adalah negara dengan pendidikan tinggi paling baik di Asia Tenggara (Quacquarelli Symonds (QS), 2018). Sehingga menjadikan KPM menjadi mitra Pemprov NTB untuk meningkatkan pengetahuan masyarakat NTB merupakan pilihan yang berdasar.

Kepentingan yang ingin dicapai melalui paradiplomasi Pemprov NTB tersebut juga mendapatkan respon yang baik dari KPM. Pihak KPM bersedia memberikan dukungan terhadap program beasiswa NTB dengan potongan biaya pendidikan dan kemudahan lainnya (Novilia, 2020; Harun, 2020). Dukungan ini membuat Pemprov NTB menjadi lebih yakin untuk menjalankan program beasiswa pendidikan tinggi ke Malaysia.

Sementara itu, pihak Malaysia memiliki alasan mereka sendiri untuk bersedia menjalin hubungan luar negeri dengan NTB. KPM dalam hal ini bersedia menjalin hubungan luar negeri dengan Pemprov NTB juga karena tujuan tertentu. Malaysia sejak tahun 2007 memiliki visi untuk menjadi "Pusat Pendidikan" di tingkat regional bahkan global (Knight \& Morshidi, 2011, hal. 601). Salah satu misi mereka untuk mewujudkan visi tersebut adalah dengan meningkatkan mahasiswa internasional hingga 250.000 pada tahun 2025 (Kementerian Pendidikan Malaysia, 2015, p. 22). Dalam hal ini, KPM melihat program Beasiswa NTB sebagai peluang besar untuk meningkatkan jumlah mahasiswa internasional mereka. Sehingga setelah mengetahui adanya program beasiswa yang sedang dibangun oleh NTB, KPM mengutus delegasi dari Kedutaan Besar Malaysia dan MDPS untuk membuka peluang hubungan pendidikan tinggi dengan NTB dan sekaligus menawarkan beasiswa pendidikan mereka untuk masyarakat NTB. 


\section{KESIMPULAN}

Penelitian ini menunjukkan bahwa paradiplomasi didorong oleh berbagai faktor. Dalam konteks ini, faktor globalisasi dan peran pemimpin daerah adalah yang paling kuat mempengaruhi paradiplomasi NTB dalam bidang pendidikan tinggi. Faktor globalisasi dalam hal ini dipandang sebagai tantangan yang membuat sumber daya manusia NTB harus bersaing dalam pasar global dan persaingan global lainnya. Namun pada saat yang bersamaan juga memberikan peluang dengan adanya globalisasi pendidikan yang dapat membantu NTB membangun sumber daya manusia berkualitas dan berdaya saing. Sementara itu, Gubernur NTB yang memiliki latar belakang sebagai seorang akademisi juga turut menentukan arah paradiplomasi NTB yang memfokuskan pada pendidikan dan peningkatan kualitas sumber daya manusia.

Adapun Malaysia bagi Pemprov NTB merupakan negara yang dapat membantu NTB memenuhi kepentingan pragmatis dalam pengembangan kualitas sumber daya manusia melalui program beasiswa ke luar negeri. Malaysia merupakan negara dengan kualitas pendidikan tinggi yang sangat baik dan menjadi salah satu pusat pendidikan di Asia Tenggara. Di samping itu, KPM juga memberikan sejumlah keuntungan seperti potongan biaya pendidikan dan kemudahan akses ke perguruan tinggi Malaysia. Sehingga hal-hal tersebut menjadi alasan bagi Pemprov NTB untuk menjalin hubungan luar negeri dengan KPM. 


\section{DAFTAR PUSTAKA}

Alisjahbana, A. S. (2017, May 8). Percepatan Pencapaian SDGs: Belajar Dari Provinsi NTB. SDG Center Unpad. http://sdgcenter.unpad.ac.id/percepatan-pencapaian-sdgs-belajar-dariprovinsi-ntb/

BPS. (2020). [Metode Baru] Indeks Pembangunan Manusia menurut Provinsi 2018-2020. Badan Pusat Statistik Indonesia. https:/ /www.bps.go.id/indicator/26/494/1/-metode-baru-indekspembangunan-manusia-menurut-provinsi.html

Chapman, D., \& Chien, C.-L. (2014). Expanding Out and Up: What are The System-Leve Dynamics? Case Study of Malaysia and Thailand. In David W. Chapman \& C.-L. Chien (Eds.), Higher Education in Asia: Expanding Out, Expanding Up (pp. 37-48). UNESCO Institute for Statistics.

Damayanti, N. (2018). Strategi Pengembangan Kerjasama Sister City Kota Semarang, Indonesia - Brisbane, Australia. EFFICIENT Indonesian Journal of Development Economics, 1(1), 51-58. https://doi.org/10.15294/efficient.v1i1.27220

Diskominfo NTB. (2018, December 18). Scholarship Hunter Serbu Pameran IESE 2018. Dinas Komunikasi, Informatika Dan Statistik NTB. https://diskominfotik.ntbprov.go.id/content/scholarship-hunter-serbupameran-beasiswa-iese-2018

Edwards, S., \& Kitamura, Y. (2019). Knowledge Diplomacy and Worldview Diversity Education: Applications for an Internationalized Higher Education Sector. In D. E. Neubauer, K. H. Mok, \& S. Edwards (Eds.), Contesting Globalization and Internationalization of Higher Education: Discourse and Responses in the Asia Pacific Region (pp. 143-162). Palgrave Macmillan. https://doi.org/10.1007/978-3-030-26230-3_11

Garesché, E. D. Z. (2007). Guidelines for the International Relations of Local Governments and Decentralised Cooperation Between the European Union 
and Latin America. Diputación de Barcelona.

Guardian. (2014, July 17). Top 20 countries for international students. The Guardian. https://www.theguardian.com/higher-educationnetwork/blog/2014/jul/17/top-20-countries-international-students

Humas NTB. (2018, December 16). Pertemuan Gubernur dengan Kedutaan Besar Malaysia dan Perwakilan Perguruan Tinggi Malaysia. Instagram Resmi Humas NTB. https://www.instagram.com/p/Brbsgf8H15P/?igshid=1bjaj5kuxp8bh

Kementerian Pendidikan Malaysia. (2015). Executive Summary: Malaysia Education Blueprint 2015-2025 (Higher Education).

Knight, J., \& Morshidi, S. (2011). The complexities and challenges of regional education hubs: Focus on Malaysia. Higher Education, 62(5), 593-606. https://doi.org/10.1007/s10734-011-9467-2

Kuznetsov, A. (2015). Theory and Practice of Paradiplomacy: Subnational Governments in International Affairs. Routledge. https://doi.org/10.4324/9781315817088

Mingus, M. (2006). Transnationalism and subnational paradiplomacy: Are governance networks perforating sovereignty? International Journal of Public Administration, 29(8), 577-594. https://doi.org/10.1080/01900690500455305

Mukti, T. A. (2013). Paradiplomacy: Kerjasama Luar Negeri Oleh Pemda Di Indonesia. The Phinisi Press.

Nur Alam, G., Maharani, R., Affandi, R. N., \& Dermawan, W. (2021). Pengembangan Ekonomi Kreatif Sebagai Paradiplomasi Kota Metropolitan Seoul. Jurnal Dinamika Global, 6(01), 1-18. https://doi.org/10.36859/jdg.v6i01.463

Paquin, S. (2004). Paradiplomacy and international relations: Theory of 
international strategies of regions facing globalization. PIE/Peter Lang.

Pemprov NTB. (n.d.-a). Beasiswa NTB. Pemrintah Provinsi Nusa Tenggara Barat. https://www.ntbprov.go.id/program-unggulan-ntb/beasiswa-ntb

Pemprov NTB. (n.d.-b). Profil Pimpinan. Pemerintah Provinsi Nusa Tenggara Barat. https://www.ntbprov.go.id/profil-pimpinan

Pemprov NTB. (2019a). 1000 Cendekia. Pemerintah Provinsi Nusa Tenggara Barat. https://www.ntbprov.go.id/program-unggulan/deskripsi/18

Pemprov NTB. (2019b). NTB dan Malaysia Tandatangani MOU Kerjasama Pendidikan. Pemerintah Provinsi Nusa Tenggara Barat. https://www.ntbprov.go.id/post/program-unggulan/ntb-dan-malaysiatandatangani-mou-kerjasama-pendidikan

Pemprov NTB. (2019c). Rencana Pembangunan Jangka Menengah Daerah Provinsi Nusa Tenggara Barat Tahun 2019-2023.

Pratama, D. P. (2020). Paradiplomacy Practice in Indonesia: a Lesson From West Nusa Tenggara Province in 2013-2019. Journal of Islamic World and Politics, 4(1). https://doi.org/10.18196/jiwp.4145

Quacquarelli Symonds (QS). (2018). QS Higher Education System Strength Ranking. QS Top Universities. https://www.topuniversities.com/systemstrength-rankings/2018

Schiavon, J. A. (2019). Comparative Paradiplomacy. Routledge. https://doi.org/10.4324/9781351012317

Subarkah, A. R. (2018). Diplomasi Pariwisata Halal Nusa Tenggara Barat. Intermestic: Journal of International Studies, 188-203.

Tavares, R. (2016). Paradiplomacy: Cities and States as Global Players. Oxford University Press.

Tubilewicz, C. (2016). Paradiplomacy as a provincial state-building project: 
The Case of Yunnan's Relations with the Greater Mekong Subregion. Foreign Policy Analysis, 13(4), 1-19. https://doi.org/10.1093/fpa/orw022

UNESCO. (n.d.). Global Flow of Tertiary-Level Students. UNESCO Institute for Statistics. http://uis.unesco.org/en/uis-student-flow\#slideoutmenu

Varghese, N. V. (2008). Globalization of higher education and cross-border student mobility. International Institute for Educational Planning (IIEP).

Zamorano, M. M., \& Morató, A. R. (2014). The cultural paradiplomacy of Barcelona since the 1980s: Understanding transformations in local cultural paradiplomacy. International Journal of Cultural Policy, 21(5), 554-576.

https://doi.org/https://doi.org/10.1080/10286632.2014.943752

\section{Wawancara}

Harun, M. H. (2020, September 18). Wawancara dengan Minister Counselor of Education Kedutaan Besar Malaysia di Jakarta Tentang Hubungan Luar Negeri Nusa Tenggara Barat dengan Kementerian Pendidikan Malaysia dalam Bidang Pendidikan Tinggi. (A. S. Bukhari, Interviewer)

Muslim, A. (2020, Agustus 27). Wawancara dengan Dinas Pendidikan Pendidikan dan Kebudayaan Nusa Tenggara Barat Tentang Kondisi Pendidikan, Program Beasiswa, dan Hubungan Luar Negeri. (A. S. Bukhari, Interviewer)

Novilia, S. H. (2020, September 8). Wawancara dengan Sekretaris Lembaga Pengembangan Pendidikan Nusa Tenggara Barat Tentang Paradiplomasi Bidang Pendidikan Tinggi. (A. S. Bukhari, Interviewer)

Saputra, L. I. (2020, Agustus 24). Wawancara dengan Kepala Bagian Kerjasama Pemerintahan Biro Kerjasama dan Administrasi NTB Tentang Paradiplomasi Pendidikan NTB. (A. S. Bukhari, Interviewer) 